\title{
Monogenoids from the gills of spiny eels (Teleostei: Mastacembelidae) in India and Iraq, proposal of Mastacembelocleidus gen. n., and status of the Indian species of Actinocleidus, Urocleidus and Haplocleidus (Monogenoidea: Dactylogyridae)
}

\author{
Delane C. Kritsky ${ }^{1}$, K.C. Pandey ${ }^{2}$, Nirupama Agrawal ${ }^{2}$ and Shamall M.A. Abdullah ${ }^{3}$ \\ ${ }^{1}$ Department of Health and Nutrition Sciences, Campus Box 8090, Idaho State University, Pocatello, Idaho 83209, USA; \\ ${ }^{2}$ Department of Zoology, University of Lucknow, Lucknow 226 001, India; \\ ${ }^{3}$ Department of Biology, College of Education, University of Salahaddin, Erbil, Iraq
}

Key words: Monogenoidea, Dactylogyridae, Mastacembelocleidus, Mastacembelocleidus bam, Mastacembelocleidus heteranchorus, Mastacembelidae, spiny eels, Macrognathus aculeatus, Macrognathus pancalus, Mastacembelus armatus, Mastacembelus mastacembelus, India, Iraq

\begin{abstract}
Mastacembelocleidus gen. n. (Monogenoidea: Dactylogyridae) is proposed to include two species collected and redescribed from spiny eels (Mastacembelidae) in India and Iraq: Mastacembelocleidus bam (Tripathi, 1959) comb. n. (syn. Ancyrocephalus bam Tripathi, 1959) from the gills of Macrognathus pancalus (new host record) and Macrognathus aculeatus (Synbranchiformes: Mastacembelidae) from Lucknow, India; and Mastacembelocleidus heteranchorus (Kulkarni, 1969) comb. n. (syn. Urocleidus heteranchorus Kulkarni, 1969) from the gills of Mastacembelus armatus from Lucknow, India, and Mastacembelus mastacembelus (new host record) from the environs of Erbil, Iraq (new locality record). Urocleidus rhyncobdelli Jain, 1959, Haliotrema tandani Agrawal et Singh, 1982 and Urocleidus raipurensis Dubey, Gupta et Agarwal, 1992 are considered junior subjective synonyms of M. bam.
\end{abstract}

The Mastacembelidae includes 5 genera and 74 species of freshwater, tropical to subtropical synbranchiform fishes commonly referred to as spiny eels (Froese and Pauly 2004). Mastacembelids occur in Africa and from Syria to the Malay Archipelago and China, are locally regarded as an excellent food fish, and occasionally are found within the aquarium market. Six nominal species of Monogenoidea (all Dactylogyridae) have been described from the gills of these fishes: Ancyrocephalus bam Tripathi, 1959 from Rhyncobdella aculeata (Bloch) [valid name, Macrognathus aculeatus (Bloch)] from a fish market in eastern India (Tripathi 1959); Urocleidus rhyncobdelli Jain, 1959 from $R$. aculeata from Lucknow, India (Jain 1959); Urocleidus heteranchorus Kulkarni, 1969 from Mastacembelus armatus (Lacepède) from Hyderabad, India (Kulkarni 1969); Haliotrema tandani Agrawal et Singh, 1982 from Macrognathus aculeatus from Lucknow, India (Agrawal and Singh 1982a); Urocleidus raipurensis Dubey, Gupta et Agarwal, 1992 from M. aculeatus and M. armatus from Raipur, India (Dubey et al. 1992); and Dactylogyrus manairensis Venkatanarsaiah, 1981 from M. aculeatus at Manair, Karimnagar, Andhra Pradesh, India (Venkatanarsaiah 1981). Spiny eels in Africa have not been found infested with monogenoids (Paperna 1979, K. Christison personal communication). Recently, dactylogyrids were found on four species of mastacembelids in India and Iraq. These collec- tions allowed taxonomic evaluations of $A$. bam, H. tandani, $U$. heteranchorus, $U$. raipurensis and $U$. rhyncobdelli, and a new genus is proposed to accommodate them.

\section{MATERIALS AND METHODS}

Fish hosts were collected by net from localities in India and Iraq. Names of hosts follow those provided in FishBase (Froese and Pauly 2004). Host gills were surgically removed and placed in vials containing hot $\left(60^{\circ} \mathrm{C}\right) 4 \%$ formalin solution for relaxation and fixation of helminths; vials were labeled and shipped to Idaho State University where helminth specimens were collected from the sediment and gill surfaces with a small probe. Some specimens were mounted unstained in Gray and Wess' medium or Malmberg's medium for study of sclerotised structures; other specimens were stained with Mayer's carmalum or Gomori's trichrome and mounted in Canada balsam to determine internal features (Malmberg 1957, Humason 1979). Illustrations were prepared with the aid of a camera lucida or microprojector. Measurements, all in micrometres, were obtained using a calibrated filar micrometer and compound microscope and are represented as the average followed by the range and number (n) of measurements taken in parentheses. Dimensions of organs and other structures represent the greatest measurement in dorsoventral view; length of the body includes that of the haptor; measurements of anchors are shown in Figs. 1, 2; the 


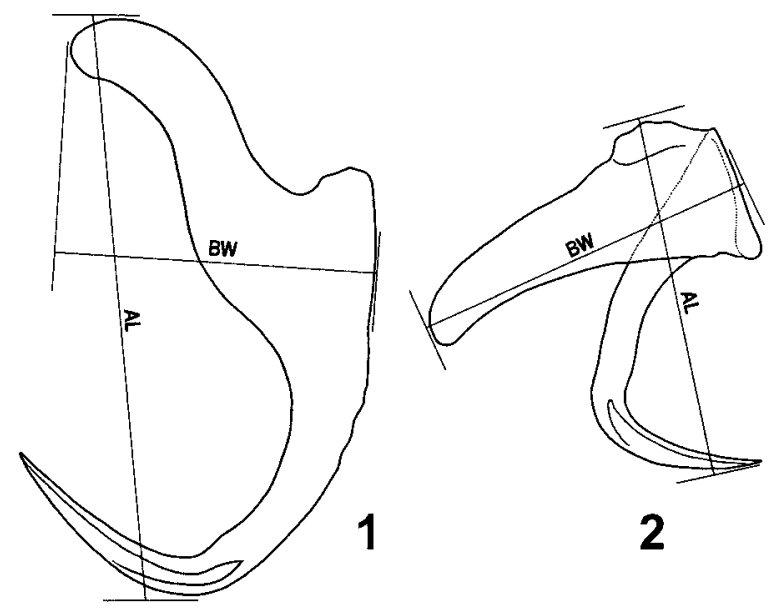

Figs. 1, 2. Measured dimensions of anchors. Fig. 1. Ventral anchor. Fig. 2. Dorsal anchor. AL - anchor length; BW - base width.

hook measurement represents total hook length. Direction of the coil of the copulatory organ (clockwise vs. counter-clockwise) was determined using the procedure suggested by Kritsky et al. (1985). Voucher specimens are deposited in the U.S. National Parasite Collection (USNPC), Beltsville, Maryland, USA and the collections of the British Museum (Natural History) $(\mathrm{BM}[\mathrm{NH}])$, London, UK and the Institute of Parasitology, Academy of Sciences of the Czech Republic (IPCAS), České Budějovice, Czech Republic. A cotype of Urocleidus heteranchorus Kul-karni, 1969, from the Museum of the Zoology Department, College of Science, Osmania University, Hyderabad, India (no museum number provided) was examined.

\section{RESULTS}

Class MonogenOIDEA Bychowsky, 1937

Subclass POLYONCHOINEA Bychowsky, 1937

D a c ty log y rida e Bychowsky, 1933

\section{Mastacembelocleidus gen. n.}

Diagnosis. Body comprising body proper (cephalic region, trunk, peduncle), haptor. Tegument smooth. Two terminal, 2 bilateral cephalic lobes; 3 pairs of bilateral head organs; cephalic glands unicellular, posterolateral to pharynx. Eyes poorly developed or absent; accessory (melanistic) granules small, irregular to subovate. Mouth subterminal, midventral, prepharyngeal; pharynx comprising muscular, glandular bulb; oesophagus short to nonexis-tant; intestinal caeca 2, confluent posterior to gonads, lacking diverticula. Common genital pore midventral near level of intestinal bifurcation. Gonads intercaecal, lying near body midlength; testis posterodorsal to ovary. Vas deferens looping left intestinal caecum; 2 seminal vesicles both dilations of vas deferens; prostatic reservoir not observed. Copulatory complex comprising disarticulated copulatory organ, accessory piece; copulatory organ sclerotised, tubular, a coil with clockwise rings; accessory piece with grooved guide for copulatory organ. Two bilateral gland-like structures lying on each side of female duct immediately anterior to ovary; seminal receptacle preovarian, ventral. Vaginal pore submarginal, ventral, dextral; vagina tubular, usually lightly sclerotised. Vitel-larium in trunk, absent from regions of other reproductive organs. Haptor with dorsal, ventral anchor/bar complexes, 7 pairs of similar hooks with ancyrocephaline distribution (Mizelle 1936, see Mizelle and Price 1963); anchors with anchor filaments; point of dorsal, ventral anchors with deep superficial groove; dorsal anchor base bent at union with shaft toward haptoral midline; ventral bar with spike-like ends directed perpendicularly from main axis of bar; dorsal bar broadly U-shaped, with ends directed laterally; hook with protruding blunt thumb, slender shank compris-ing single unit. Parasites of gills of spiny eels (Masta-cembelidae). Type species: Mastacembelocleidus bam (Tripathi, 1959) comb. n.

E t y m o 1 o g y : The generic name indicates the family of fishes that serve as hosts for species of the genus.

Remarks. The Dactylogyridae includes more than 200 genera representing marine and freshwater species occurring throughout the world. Mastacembelocleidus resembles those genera whose species possess tandem or slightly overlapping gonads, a dextral vagina, a coiled male copulatory organ, dorsal and ventral anchor/bar complexes, and hooks with shanks comprising one slender unit. Morphology of the haptoral anchors and bars and of the copulatory organ appears to best distinguish Mastacembelocleidus from all other genera of Dactylogyridae. Species of Mastacembelocleidus possess 1) bases of the dorsal anchors folded toward the midline of the haptor, 2) a ventral bar with spike-like ends directed perpendicular to the long axis of the bar, 3) a broadly U-shaped dorsal bar with ends directed laterally, 4) dorsal and ventral anchors with a deep groove along the superficial surface of the point, and 5) a coiled copulatory organ with clockwise rings. In well-preserved specimens, two bilateral gland-like structures are visible on each side of the female duct immediately anterior to the ovary. These structures may represent the Mehlis' gland, although ducts were not evident in any of the available specimens.

Species of Mastacembelocleidus possess dorsal anchors with bases bent toward the midline of the haptor. This feature also occurs in some marine and freshwater species of other dactylogyrid genera, i.e., Haliotrema Johnston et Tiegs, 1922, Euryhaliotrema Kritsky et Boeger, 2002 and Euryhaliotrematoides Plaisance et Kritsky, 2004. While phylogenetic relationships are generally unknown within the Dactylogyridae, folded anchor bases in species of Mastacembelocleidus likely represent an example of convergence rather than a phylogenetic relationship with species of these genera. 
Mastacembelocleidus bam (Tripathi, 1959) comb. n.

Figs. 3-11

Synonyms. Ancyrocephalus bam Tripathi, 1959; Urocleidus rhyncobdelli Jain, 1959; Haplocleidus rhyncobdelli (Jain, 1959) Yamaguti, 1963; Gussevia rhynchobdelli (Jain, 1959) Kohn et Paperna, 1964; Haliotrema tandani Agrawal et Singh, 1982; Urocleidus raipurensis Dubey, Gupta et Agarwal, 1992.

Redescription. Trunk fusiform, greatest width usually posterior to gonads; peduncle broad, slightly tapered posteriorly. Cephalic lobes, head organs well developed. Eyes granules usually dispersed, scattered throughout cephalic region, anterior trunk. Pharynx subspherical. Testis subovate; seminal vesicles fusiform, distal vesicle lying dorsal to copulatory complex; copulatory organ delicate, with 2 rings, elongate bulbous base; accessory piece club-shaped, with rod-like guide for copulatory organ, subterminal knife-like blade, distal recurved arm. Ovary elongate ovate; uterus extending ventrally along body midline, with comparatively heavy wall; vagina with bulbous termination, distal loop dorsal to vaginal bulb, extending posteriorly to irregular seminal receptacle; small indentation on dextrolateral body margin apparently site of vaginal aperture; tegument frequently modified around tegumental indentation. Vitellarium dense. Haptor subtrapezoidal. Each ventral anchor with elongate evenly arced superficial root, short blunt deep root, arced shaft with slight undulation at union with elongate point; each dorsal anchor with undulation at union of shaft, point. Ventral bar rod-shaped, with parallel anterior, posterior margins; terminal spines directed anteriorly or ventrally. Dorsal bar with tapered ends. Hooks delicate; filamentous hook loops nearly shank length. Measurements: Table 1.

$\mathrm{Hos} \mathrm{s}$ a n d 1 o c a 1 i t i e s: Macrognathus aculeatus (Bloch): Gomti River near the Daliganj and Nishatganj bridges, $1 \mathrm{~km}$ from the campus of the University of Lucknow, Lucknow, India (26 ${ }^{\circ} 45.27^{\prime} \mathrm{N}$; 80 $\left.50.81^{\prime} \mathrm{E}\right)$ (4 March 2004). Macrognathus pancalus (Hamilton): Gomti River near the Daliganj and Nishatganj bridges, $1 \mathrm{~km}$ from the campus of the University of Lucknow, Lucknow, India (2 February 2004)

S i t e : Gills.

Previ o u s r e c o rd s: Macrognathus aculeatus (type host): as Ancyrocephalus bam from a fish market, eastern India (Tripathi 1959); as Urocleidus rhynchobdelli from Lucknow, India (Jain 1959); as Haliotrema tandani from Lucknow, India (Agrawal and Singh 1982a); as Urocleidus raipurensis from Raipur, India (Dubey et al. 1992). Mastacembelus armatus: as Urocleidus raipurensis from Raipur, India (Dubey et al. 1992).

$\mathrm{S}$ p e c i m e n s s t ud i ed: 34 voucher specimens (from $M$. pancalus), USNPC 94862, BM(NH) 2004.6.9.21-30, IPCAS M-403; 6 voucher specimens (from M. aculeatus), USNPC 94863.

Remarks. We have frequently collected and examined many specimens of Macrognathus aculeatus for gill para- sites. Although four similar species of Dactylogyridae have been previously described from this host in India (i.e., Ancyrocephalus bam, Haliotrema tandani, Urocleidus rhyncobdelli and U. raipurensis), only one species was consistently found. Type specimens of these species were apparently not preserved by their respective authors or have been subsequently lost or destroyed, and assignment of a specific name to present specimens depended on comparison with respective published accounts. The original descriptions of $A$. bam and $U$. rhyncobdelli were both published in 1959 by Tripathi (January 30) and Jain (April 30), respectively, while those of $H$. tandani and $U$. raipurensis appeared in 1982 and 1992, respectively (Agrawal and Singh 1982a, Dubey et al. 1992). These four species are herein considered synonyms, with Tripathi's (1959) name having priority.

The original description of $A$. bam is generally nonspecific and includes highly diagrammatic figures. That present specimens are conspecific with $A$. bam is suggested in Tripathi's fig. 21a, where a distal bulb-like expansion of the vaginal duct is shown, although the distal loop of the vaginal canal is not depicted. In the original description of $A$. bam, the dorsoventral axis of the haptor is reversed as suggested by the assignment of the larger pair of anchors to a dorsal position. Tripathi's depiction of the copulatory complex (fig. 21b) is a poor representation of the accessory piece and the delicate coiled copulatory organ is not shown; Tripathi apparently confused the guide for the copulatory organ in the accessory piece as the copulatory organ, and the structure labeled " $\mathrm{P}=$ prostate gland reservoir" in his fig. 21a is likely the bulbous base of the copulatory organ (see Fig. 4 herein). While Tripathi (1959) indicates that A. bam has two pairs of eyes, his drawing only depicts three; eyes are absent or represent disorganized groupings of melanistic granules in present specimens.

The description of $U$. rhyncobdelli was published almost simultaneously with that of $A$. bam and it is likely that Jain (1959) was justifiably unaware of Tripathi's (1959) work. Although many discrepancies between Jain's (1959) description and present specimens exist, we consider $U$. rhyncobdelli a junior synonym of $A$. bam. Jain (1959) collected $M$. aculeatus from unspecified sites near Lucknow, India, and like our observations, only found one species infesting this host. Jain (1959) indicated that the larger anchors are dorsal in the haptor, suggesting that the dorsoventral axis of the haptor was reversed in the original description. While the bulbous termination of the vagina is shown in the original description, Jain (1959) indicates that it represents the proximal portion of the vaginal duct; he also observed a portion of the distal loop of the vaginal duct but thought that the duct ended at the surface of the body at the vaginal pore. Jain (1959) shows the coiled copulatory organ with approximately four rings, but it is likely that he confused a portion of the accessory piece as some of the rings of the coil. 


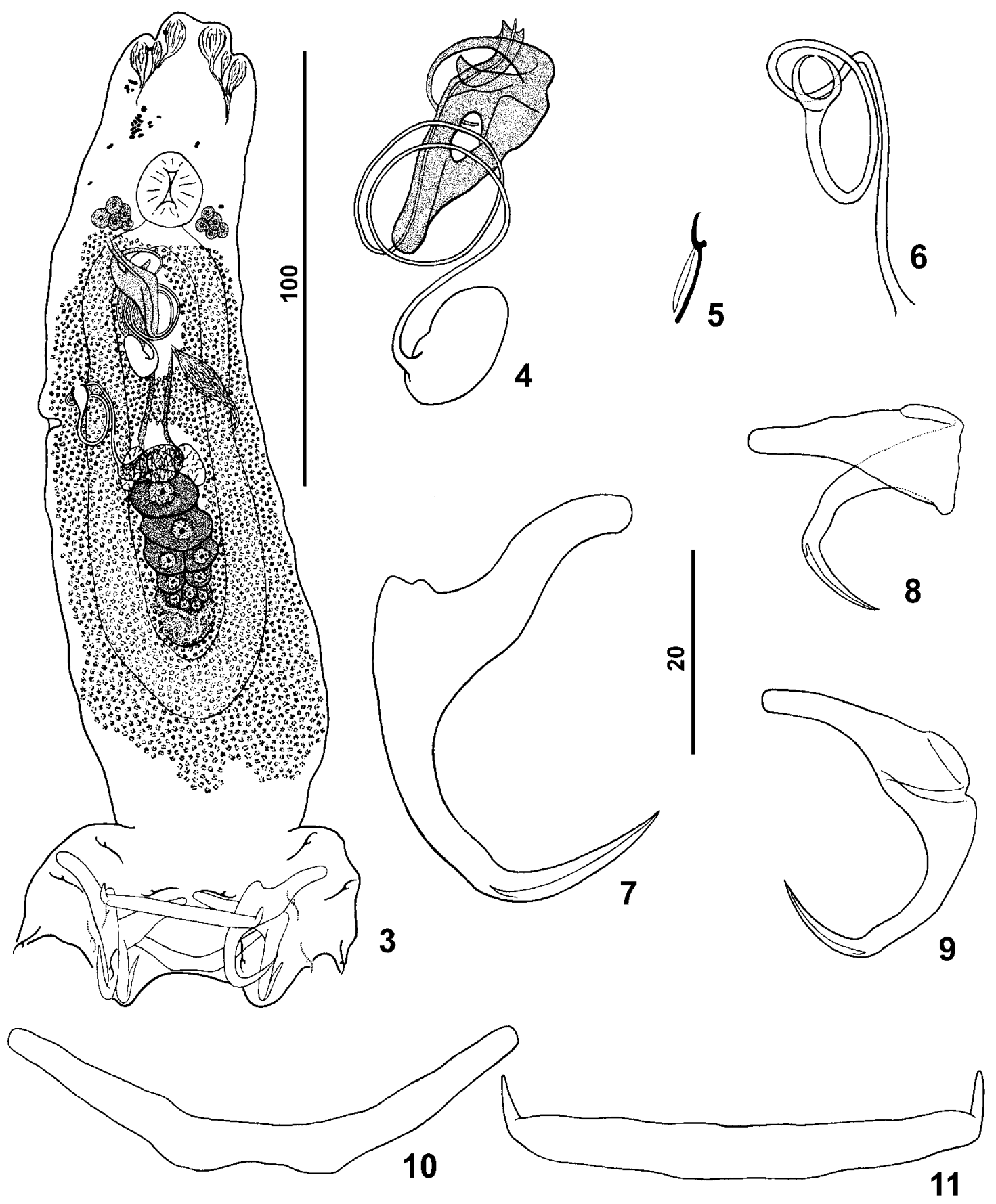

Figs. 3-11. Mastacembelocleidus bam (Tripathi, 1959) comb. n. from Macrognathus pancalus. Fig. 3. Whole mount (composite, ventral view). Fig. 4. Copulatory complex (dorsal view). Fig. 5. Hook. Fig. 6. Vagina (ventral view). Fig. 7. Ventral anchor. Fig. 8. Dorsal anchor (normal configuration). Fig. 9. Dorsal anchor (flattened). Fig. 10. Dorsal bar. Fig. 11. Ventral bar. All figures are drawn to the $20 \mu \mathrm{m}$ scale except Fig. 3 (100 $\mu \mathrm{m}$ scale).

The description of $U$. raipurensis by Dubey et al. (1992) closely fits the characters depicted by our specimens and there is little doubt that they are conspecific. Although Agrawal and Singh (1982a) describe the gut of Haliotrema tandani from Macrognathus aculeatus to be non-confluent, this species is also a junior synonym of $M$. bam. Both groups of investigators confused the dorsoventral axis of the haptor in the original descriptions of the respective species. 
Table 1. Comparative measurements of Mastacembelocleidus bam and M. heteranchorus from respective hosts and localities.

\begin{tabular}{|c|c|c|c|c|}
\hline & $\begin{array}{l}\text { M. bam } \\
\text { Host: } \text { M. pancalus } \\
\text { Lucknow, India }\end{array}$ & $\begin{array}{l}\text { M. bam } \\
\text { Host: } \text { M. aculeatus } \\
\text { Lucknow, India }\end{array}$ & $\begin{array}{l}\text { M. heteranchorus } \\
\text { Host: } M . \text { armatus } \\
\text { Lucknow, India }\end{array}$ & $\begin{array}{l}\text { M. heteranchorus } \\
\text { Host: } \text { M. mastacembelus } \\
\text { Erbil, Iraq }\end{array}$ \\
\hline $\begin{array}{l}\text { Body } \\
\text { Length } \\
\text { Width }\end{array}$ & $\begin{array}{c}245(188-308 ; \mathrm{n}=11) \\
64(45-83 ; \mathrm{n}=10)\end{array}$ & $\begin{array}{c}339(291-380 ; \mathrm{n}=3) \\
75(67-83 ; \mathrm{n}=3)\end{array}$ & $\begin{array}{c}373(248-500 ; \mathrm{n}=14) \\
88(71-108 ; \mathrm{n}=15)\end{array}$ & $\begin{array}{c}533(365-713 ; \mathrm{n}=20) \\
81(63-93 ; \mathrm{n}=20)\end{array}$ \\
\hline $\begin{array}{l}\text { Haptor } \\
\text { Length } \\
\text { Width }\end{array}$ & $\begin{array}{l}53(45-62 ; \mathrm{n}=11) \\
77(67-89 ; \mathrm{n}=10)\end{array}$ & $\begin{array}{l}60(51-67 ; n=3) \\
74(61-83 ; n=3)\end{array}$ & $\begin{array}{l}73(57-102 ; \mathrm{n}=12) \\
91(78-99 ; \mathrm{n}=12)\end{array}$ & $\begin{array}{l}84(71-103 ; n=15) \\
91(79-105 ; n=16)\end{array}$ \\
\hline Pharynx Width & $19(15-23 ; n=12)$ & $22(19-24 ; n=3)$ & $26(20-32 ; n=16)$ & $28(23-35 ; n=16)$ \\
\hline $\begin{array}{c}\text { Copulatory organ } \\
\text { Ring diameter }\end{array}$ & $18(16-21 ; n=14)$ & $19(16-22 ; n=4)$ & $13(10-16 ; n=2)$ & $12(9-14 ; n=2)$ \\
\hline $\begin{array}{l}\text { Accessory piece } \\
\text { Length }\end{array}$ & $26(22-30 ; \mathrm{n}=18)$ & $29(26-30 ; n=5)$ & $23(21-25 ; n=9)$ & $22(19-24 ; n=8)$ \\
\hline $\begin{array}{l}\text { Testis } \\
\text { Length } \\
\text { Width }\end{array}$ & $\begin{array}{l}19(14-24 ; n=5) \\
16(14-18 ; n=5)\end{array}$ & $\begin{array}{l}- \\
- \\
\end{array}$ & $\begin{array}{l}22(17-25 ; n=6) \\
13(11-16 ; n=6)\end{array}$ & $\begin{array}{l}24(20-29 ; \mathrm{n}=8) \\
17(13-20 ; \mathrm{n}=8)\end{array}$ \\
\hline $\begin{array}{l}\text { Ovary } \\
\text { Length } \\
\text { Width }\end{array}$ & $\begin{array}{l}32(20-46 ; n=6) \\
18(15-25 ; n=6)\end{array}$ & $\begin{array}{l}56(48-64 ; \mathrm{n}=3) \\
23(20-27 ; \mathrm{n}=3)\end{array}$ & $\begin{array}{l}64(40-80 ; \mathrm{n}=13) \\
27(20-34 ; \mathrm{n}=13)\end{array}$ & $\begin{array}{l}59(48-75 ; n=14) \\
24(20-29 ; n=14)\end{array}$ \\
\hline $\begin{array}{l}\text { Ventral anchor } \\
\text { Length } \\
\text { Base width }\end{array}$ & $\begin{array}{l}40(36-44 ; \mathrm{n}=20) \\
23(20-28 ; \mathrm{n}=15)\end{array}$ & $\begin{array}{l}41(38-43 ; n=6) \\
23(22-24 ; n=4)\end{array}$ & $\begin{array}{c}53(48-57 ; \mathrm{n}=12) \\
31(27-36 ; \mathrm{n}=9)\end{array}$ & $\begin{array}{l}50(46-54 ; n=19) \\
30(27-33 ; n=10)\end{array}$ \\
\hline $\begin{array}{l}\text { Dorsal anchor } \\
\text { Length } \\
\text { Base width } \\
\end{array}$ & $\begin{array}{l}25(20-27 ; n=13) \\
25(19-29 ; n=13)\end{array}$ & $\begin{array}{l}26(24-27 ; \mathrm{n}=5) \\
26(24-27 ; \mathrm{n}=4)\end{array}$ & $\begin{array}{l}32(28-38 ; \mathrm{n}=12) \\
34(30-38 ; \mathrm{n}=13)\end{array}$ & $\begin{array}{l}32(29-33 ; \mathrm{n}=16) \\
30(26-34 ; \mathrm{n}=17)\end{array}$ \\
\hline Ventral bar & $47(42-53 ; n=22)$ & $47(42-51 ; n=4)$ & $63(54-76 ; n=19)$ & $55(47-65 ; n=21)$ \\
\hline Dorsal bar & $43(37-50 ; n=22)$ & $45(40-49 ; n=4)$ & $55(49-61 ; \mathrm{n}=19)$ & $50(44-61 ; n=20)$ \\
\hline Hook & $12-13(n=10)$ & $12-13(n=1)$ & $14(12-15 ; n=13)$ & $14(13-16 ; n=22)$ \\
\hline
\end{tabular}

Because we consider A. bam, H. tandani, U. rhyncobdelli and $U$. raipurensis conspecific and $A$. bam has priority, present specimens are named Mastacembelocleidus bam (Tripathi, 1959) comb. n. The reassignments of $U$. rhyncobdelli to Haplocleidus and Gussevia by Yamaguti (1963) and Kohn and Paperna (1964), respectively, are also synonyms of $M$. bam. The latter reassignments are unjustified because species of Haplocleidus are exclusively Nearctic and those of Gussevia are Neotropical (see Beverley-Burton and Suriano 1980, Kritsky et al. 1986, respectively).

Mastacembelocleidus bam apparently occurs on Macrognathus spp. (M. aculeatus and $M$. pancalus) from throughout its hosts' ranges in India, having been previously reported from Madhya Pradesh and Uttar Pradesh (Jain 1959, Agrawal and Singh 1982a, Dubey et al. 1992); the record by Tripathi (1959) is not specific, although his specimens were likely collected in eastern India as well. The record of M. bam on Mastacembelus armatus by Dubey et al. (1992) requires verification. In our collections of M. armatus, we found only Mastacembelocleidus heteranchorus and the possibility of misidentification or contamination cannot be discounted. Our finding of $M$. bam on M. pancalus is a new host record for this species.

Mastacembelocleidus bam is the type species of the genus. It differs from its congener, $M$. heteranchorus, by having a more robust subtriangular accessory piece in the copulatory complex (accessory piece delicate and slender in $M$. heteranchorus) and a vagina with a distal loop and bulbous expansion (vagina inconspicuous, a straight tube in M. heteranchorus).

Mastacembelocleidus heteranchorus (Kulkarni, 1969) comb. n. Figs. 12-19

Synonym. Urocleidus heteranchorus Kulkarni, 1969.

Redescription. Body proper with parallel lateral margins along trunk, tapered cephalic region, short broad peduncle; greatest width usually posterior to gonads. Cephalic lobes, head organs well developed. Eyes poorly developed or absent; accessory granules scattered throughout cephalic region, anterior trunk. Pharynx subovate. Testis subspherical; seminal vesicles not observed; copulatory organ delicate, with 2 rings, ovate bulbous base; accessory piece with rod-like guide frequently appearing hollow, distal sinistral spine slightly curved toward tip of copulatory guide, dextral arm usually straight. Ovary ovate; uterus extending ventrally along body midline, with comparatively heavy wall; vagina a delicate straight tube (observed only in living specimens). Haptor subtrapezoidal. Ventral anchor with elongate evenly arced superficial root, short blunt deep root, arced shaft with slight undulation at union with elongate point; dorsal anchor with slight undulation at union of shaft, point. Ventral bar rod-shaped, with nearly parallel 


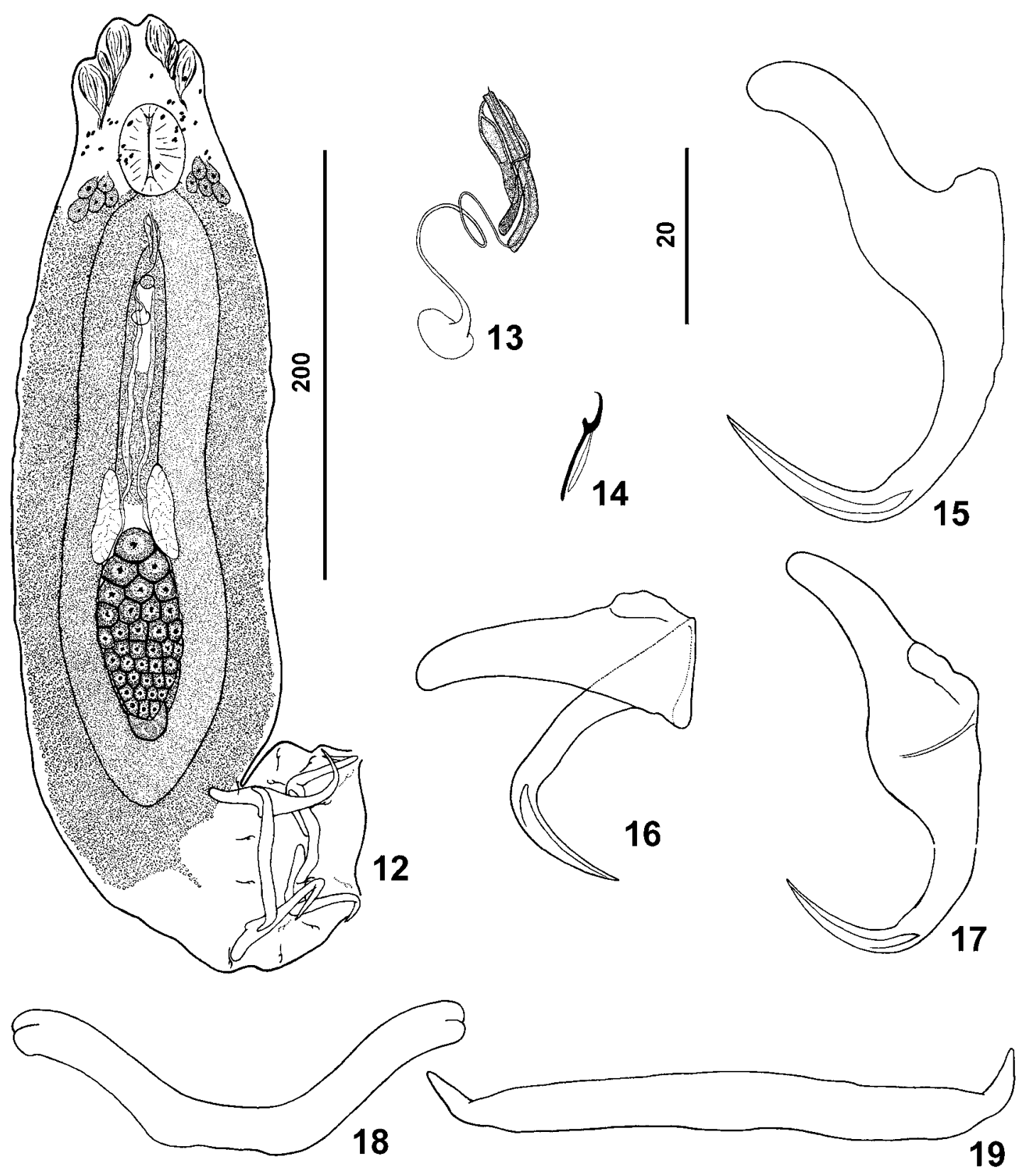

Figs. 12-19. Mastacembelocleidus heteranchorus (Kulkarni, 1969) comb. n. from Mastacembelus armatus. Fig. 12. Whole mount (composite, ventral view). Fig. 13. Copulatory complex (ventral view). Fig. 14. Hook. Fig. 15. Ventral anchor. Fig. 16. Dorsal anchor (normal configuration). Fig. 17. Dorsal anchor (flattened). Fig. 18. Dorsal bar. Fig. 19. Ventral bar. All figures are drawn to the 20 $\mu \mathrm{m}$ scale except Fig. 12 (200 $\mu \mathrm{m}$ scale).

anterior, posterior margins; terminal spines directed anteriorly or ventrally. Dorsal bar with ends frequently appearing bifid. Hook delicate; filamentous hook loop nearly shank length. Measurements: Table 1.

$\mathrm{H}$ o s t s a n d 1 o c a 1 i t i e s : Mastacembelus armatus (Lacepède): Gomti River near the Daliganj and Nishatganj bridges, $1 \mathrm{~km}$ from the campus of the University of Lucknow, Lucknow, India (265 $\left.45.27^{\prime} \mathrm{N} ; 80^{\circ} 50.81^{\prime} \mathrm{E}\right)(8$ December 2003). Mastacembelus mastacembelus (Banks et Solander): Greater Zab River, near Iski-Kalak, $40 \mathrm{~km}$ west of Erbil, Iraq (36 $\left.6^{\circ} 3^{\prime} \mathrm{N} ; 4^{\circ} 42^{\prime} \mathrm{E}\right)$ (4-14 March 2004).
S i t e : Gills.

P re vi o u s r e c o r d: Mastacembelus armatus: as Urocleidus heteranchorus from Hyderabad, India (Kulkarni 1969).

S p e c i m e n s s t u d i e d : 33 voucher specimens (from $M$. armatus), USNPC 94861, BM(NH) 2004.6.9.1-10, IPCAS M-404; 30 voucher specimens (from M. mastacembelus), USNPC 94860, BM(NH) 2004.6.9.11-20, IPCAS M-404; cotype, Urocleidus heteranchorus (from M. armatus), Osmania University. 
Remarks. Kulkarni (1969) described this species as Urocleidus heteranchorus from the gills of Mastacembelus armatus from Hyderabad, India. Examination of a cotype verified that our specimens were conspecific with his species. Kulkarni (1969) confused the guide of the accessory piece for the copulatory organ and missed the delicate copulatory organ, which was usually obscured by the vitellarium in our specimens. His measurements of the copulatory organ (18-24 $\mu \mathrm{m}$ in length) compares to that of the accessory piece in our specimens $(21-25 \mu \mathrm{m}$ in length). Kulkarni (1969) reversed the dorsoventral axis of the haptor in his description of the species. Mastacembelocleidus heteranchorus differs from M. bam by possessing a delicate accessory piece and an indistinct vagina.

The present report of M. heteranchorus on Mastacembelus mastacembelus in Iraq represents new host and locality records for this species.

\section{DISCUSSION}

Continental Drift Theory suggests that the Indian Subcontinent would have an embedded and unique dactylogyrid fauna with affinities to that occurring on the African and Asian continents. Yet, many investigators working on the parasites of fishes in India have frequently utilized genera proposed for North American species to accommodate Indian species of Dactylogyridae, i.e., Urocleidus Mueller, 1934, Haplocleidus Mueller, 1937 and Actinocleidus Mueller, 1937 (see Tripathi 1959, Jain 1952, 1955, 1959, 1961, Kulkarni 1969, Agarwal and Singh 1982, Agrawal and Singh 1982a, b, Pandey and Mehta 1986, Dubey et al. 1992, among others). That many of these Indian species were originally misplaced in these genera likely was a result of a general poor understanding of the morphological boundaries of dactylogyrid genera during early surveys in India. Subsequently, Beverley-Burton (1984) limited Urocleidus to three species [U. aculeatus (Van Cleave et Mueller, 1932) Mueller, 1934; U. adspectus Mueller, 1936; and U. baldwini (Dechtiar, 1974) Beverley-Burton, 1984] parasitizing the gills of North American freshwater fishes of the Percidae and Percopsidae. Beverley-Burton and Suriano (1980) redefined Haplocleidus based on their observations of the type species, H. dispar (Mueller, 1936) Mueller, 1937, and suggested that four species from centrarchid fishes from North America belonged to the genus. Finally, BeverleyBurton (1986) redefined Actinocleidus for 17 dactylogyrid species (9 of which were considered species inquirendae) from the gills of centrarchid fishes in North America. Beverley-Burton $(1984,1986)$ and Beverley-Burton and Suriano (1980) did not comment on the assignments to these genera made by Indian investigators. However, Gussev (1976) recognised that these latter assignments were inappropriate, and based on his collections from
India, transferred Haplocleidus octotylus Kulkarni, 1969 to Silurodiscoides Gussev, 1976, which is currently considered a synonym of Thaparocleidus Jain, 1952 by Lim (1996). Other Indian species of Urocleidus and Haplocleidus have since been transferred to genera associated predominantly with dactylogyrids of Asia and the Indian subcontinent (see Gussev and Fernando 1973, Lim 1996, Pandey et al. 2003).

In the present paper, three nominal species from India are removed from Urocleidus to Mastacembelocleidus as either a reassignment or as synonyms of the two valid species of the genus. Remaining species from India that are currently included in Urocleidus or Actinocleidus include Actinocleidus leiognathi Tripathi, 1959 from Leiognathus edentulus (Bloch) [valid name, Leiognathus equulus (Forsskål)], Leiognathidae; Urocleidus xenentodonti Jain, 1959 from Xenentodon cancila (Hamilton), Belonidae; Urocleidus mirgalae Kulkarni, 1969 from Mirgala mirgala (no reference to this fish in FishBase); Urocleidus behuri Agrawal et Singh, 1982 from Nandus nandus (Hamilton), Nandidae; Urocleidus bhoopi Agrawal et Singh, 1982 from Xenentodon cancila; Urocleidus vacha (Tripathi, 1959) Agrawal et Singh, 1982 from Eutropiichthys vacha (Hamilton), Schilbeidae; and Urocleidus recurvatus Jain, 1961 from Ambassis nama (Hamilton) (valid name, Chanda nama Hamilton), Ambassidae. All of these species are herein considered incertae sedis until appropriate generic placement and/or synonymy are determined.

Species of Mastacembelocleidus appear to be parasites specifically of spiny eels (Mastacembelidae) in Asia. Dactylogyrids have not been found on mastacembelid eels in Africa, although these fishes have been occasionally examined for gill parasites. Further, the two species of Mastacembelocleidus appear to exhibit specificity for members of their respective host genera with M. bam found only on species of Macrognathus and M. heteranchorus on species of Mastacembelus. The finding of $M$. heteranchorus on widely separated and disjunct species of Mastacembelus in India and Iraq suggests that parasite diversification has lagged behind that of their hosts, although coevolutionary processes apparently have been in play during development of the genus. Additional collections of dactylogyrids from these hosts in Asia and Africa should prove valuable for future coevolutionary studies.

Acknowledgements. The authors thank David Gibson, British Museum (Natural History), London, for providing publication dates of issues of some Indian journals. We are grateful to Wilma Jogunoori, Forest Park, Illinois, and J. Venkatanarsaiah, Osmania University, Hyderabad, India, for locating and providing a type specimen of Urocleidus heteranchorus Kulkarni, 1969. We also thank Dr. Jaya Sharma, University of Lucknow, Lucknow, India, for help in collecting hosts. 


\section{REFERENCES}

AGARWAL N., SINGH H.S. 1982: On three known monogenetic trematodes from fresh water fishes of U.P. Sci. Environ. 4: 35-42.

AGRAWAL N., SINGH H.S. 1982a: On three new monogeneans from fresh water fishes at District Lucknow. Reading Zool. 1: 31-35.

AGRAWAL N., SINGH H.S. 1982b: On a known and three unknown monogenetic Urocleidus Mueller 1934. Pranikee 3 (1981): 22-34.

BEVERLEY-BURTON M. 1984: Monogenea and Turbellaria. In L. Margolis and Z. Kabata (Eds.), Guide to the Parasites of Fishes of Canada. Part I. Can. Spec. Publ. Fish. Aquat. Sci. 74. Fisheries and Oceans, Ottawa, pp. 5-209.

BEVERLEY-BURTON M. 1986: The taxonomic status of Actinocleidus Mueller, 1937; Anchoradiscus Mizelle, 1941; Clavunculus Mizelle et al., 1956; Anchoradiscoides Rogers, 1967; Syncleithrium Price, 1967 and Crinicleidus n. gen.: North American ancyrocephalids (Monogenea) with articulating haptoral bars. J. Parasitol. 72: 22-44.

BEVERLEY-BURTON M., SURIANO M. 1980: Haplocleidus dispar (Mueller, 1936) and Pterocleidus acer (Mueller, 1936) (Monogenea: Ancyrocephalinae) from Lepomis gibbosus L. (Pisces: Centrarchidae) in Ontario, Canada: anatomy and systematic position. Can. J. Zool. 58: 661-669.

DUBEY A., GUPTA A.K., AGARWAL S.M. 1992: Studies on monogenean parasites of fresh water fishes at Raipur. X. Taxonomic discussion on the validity of the genus Urocleidus (Mueller, 1934) Mueller, 1936 (Ancyrocephalinae) and description of a new species from Mastacembelus armatus and Macrognathus aculeatus at Raipur. Indian J. Helminthol. 44: 116-122.

FROESE R., PAULY D. 2004: FishBase. World Wide Web electronic publication. www.fishbase.org, version (06/2004).

GUSSEV A.V. 1976: Freshwater Indian Monogenoidea. Principles of systematics, analysis of the world faunas and their evolution. Indian J. Helminthol. 25 \& 26: 1-241.

GUSSEV A.V., FERNANDO C.H. 1973: Dactylogyridae (Monogenoidea) from the stomach of fishes. Folia Parasitol. 20: 207-212.

HUMASON G.L. 1979: Animal Tissue Techniques, 4th ed. W.H. Freeman and Company, San Francisco, California, 661 pp.

JAIN S.L. 1952: Monogenea of Indian fresh-water fishes. I. Haplocleidus gomtius n. sp. (Sub-Family: Tetraonchinae) from the gills of Wallagonia attu (Bloch), from Lucknow. Indian J. Helminthol. 4: 37-42.

JAIN S.L. 1955: Monogenea of Indian fresh-water fishes. III. Urocleidus notopterus $\mathrm{n}$. sp. (Subfamily Tetraonchinae), from the gills of Notopterus notopterus (Pallas), from Lucknow. Proc. Indian Acad. Sci. 41: 31-37.

JAIN S.L. 1959: New species of the genus Urocleidus Mueller, 1934, from the gill filaments of some Indian fishes. J. Zool. Soc. India 10: 155-164.
JAIN S.L. 1961: Three new species of Urocleidus Mueller 1934, with a proposal of its synonymy with Haplocleidus Mueller 1937. Ann. Zool. 3: 135-148.

KOHN A., PAPERNA I. 1964: Monogenetic trematodes from aquarium fishes. Rev. Brasil. Biol. 24: 145-149.

KRITSKY D.C., BOEGER W.A., THATCHER V.E. 1985: Neotropical Monogenea. 7. Parasites of the pirarucu, $\mathrm{Ara}$ paima gigas (Cuvier), with descriptions of two new species and redescription of Dawestrema cycloancistrium Price and Nowlin, 1967 (Dactylogyridae: Ancyrocephalinae). Proc. Biol. Soc. Wash. 98: 321-331.

KRITSKY D.C., THATCHER V.E., BOEGER W.A. 1986: Neotropical Monogenea. 8. Revision of Urocleidoides (Dactylogyridae, Ancyrocephalinae). Proc. Helminthol. Soc. Wash. 53: 1-37.

KULKARNI T. 1969: Studies on the monogenetic trematodes of fishes found in Hyderabad, Andhra Pradesh (India) - Part II. Riv. Parassitol. 30: 263-282.

LIM L.H.S. 1996: Thaparocleidus Jain, 1952, the senior synonym of Silurodiscoides Gussev, 1976 (Monogenea: Ancylodiscoidinae). Syst. Parasitol. 35: 207-215.

MALMBERG G. 1957: Om förekomsten av Gyrodactylus på svenska fiskar. Särtryck ur Skrifter utgivna av Södra Sveriges Fiskeriförening, Årsskrift 1956, 19-76.

MIZELLE J.D. 1936: New species of trematodes from the gills of Illinois fishes. Am. Midl. Nat. 17: 785-806.

MIZELLE J.D., PRICE C.E. 1963: Additional haptoral hooks in the genus Dactylogyrus. J. Parasitol. 49: 1028-1029.

PANDEY K.C., AGRAWAL N., VISHWAKARMA P., SHARMA J. 2003: Redescription of some Indian species of Thaparocleidus Jain, 1952 (Monogenea), with aspects of the developmental biology and mode of attachment of $T$. pusillus (Gusev, 1976). Syst. Parasitol. 54: 207-221.

PANDEY K.C., MEHTA T. 1986: Studies on some new monogenetic trematodes of Wallago attu (Bloch) at Meerut, Uttar Pradesh, India. Proceedings of the 2nd National Convention of Young Scientists, 22-24 June 1985, Meerut University, Meerut, U. P., India, pp. 114-132.

PAPERNA I. 1979: Monogenea of inland water fish in Africa. Ann. Mus. R. Afr. Cent., Ser. Quatro Sci. Zool., 226: 1-131, 48 plates.

TRIPATHI Y.R. 1959: Monogenetic trematodes from fishes of India. Indian J. Helminthol. 9: 1-149.

VENKATANARSAIAH J. 1981: New monogenetic trematodes of the genus Dactylogyrus, Diesing, 1850 from fresh water fishes of Andhra Pradesh, India. J. Anim. Morphol. Physiol. 28: $15-20$

YAMAGUTI S. 1963: Systema Helminthum. Vol. IV. Monogenea and Aspidocotylea. Interscience Publishers, New York, New York, 699 pp.

Accepted 2 September 2004 